Article

\title{
Broadening Our Understanding of Hurricanes and Forests on the Caribbean Island of Puerto Rico: Where and What Should We Study Now?
}

\author{
Tania López-Marrero ${ }^{1, *(1)}$, Tamara Heartsill-Scalley ${ }^{2}$, Carlos F. Rivera-López ${ }^{3}$, \\ Isabel A. Escalera-García ${ }^{4}$ and Mariangelí Echevarría-Ramos ${ }^{3}$ \\ 1 Department of Social Sciences and Interdisciplinary Center for Coastal Studies, University of Puerto Rico, \\ Mayagüez, PR 00681, USA \\ 2 USDA Forest Service, International Institute of Tropical Forestry and Department of Environmental Sciences, \\ University of Puerto Rico, Río Piedras, PR 00926, USA \\ 3 Department of Biology and Interdisciplinary Center for Coastal Studies, University of Puerto Rico, \\ Mayagüez, PR 00681, USA \\ 4 Department of Agro-Environmental Sciences and Interdisciplinary Center for Coastal Studies, \\ University of Puerto Rico, Mayagüez, PR 00681, USA \\ * Correspondence: tania.lopez1@upr.edu; Tel.: +1-787-265-3839
}

Received: 11 July 2019; Accepted: 19 August 2019; Published: 21 August 2019

\begin{abstract}
Hurricanes shape ecosystems. A broad range of forested ecosystems is particularly affected by hurricanes, thus creating the need for studies addressing the effects of these disturbances. There is a long history of hurricane and forest research on the Caribbean island of Puerto Rico. In this study, we present results from a systematic literature review of peer-reviewed articles regarding ecological research conducted in Puerto Rico on the topic of hurricanes and forests published from 1900 through 2017. We present a summary of cyclonic activity on the island during the study period and the results from the systematic literature review within this cyclonic context. We discuss findings in terms of aspects of forests studied, geographical distribution of study areas, and time scales at which research was conducted. These findings allow us to determine what was studied about hurricanes and forests, identify gaps in the information, and suggest possible areas of research and production of new knowledge that recent and future storms can bring. We conclude with recommendations identifying research needs and propose additional approaches to complement existing information. Our goal is to generate future knowledge from hurricane and forest research with the broadest applications possible.
\end{abstract}

Keywords: hurricanes; forests; Puerto Rico; systematic literature review; ecological research

\section{Introduction}

Hurricanes are of high impact to social-ecological systems. In the case of forest ecosystems, they cause a range of effects to forest vegetation and biota. These effects include long-term processes of natural selection, and short-term effects on structure, composition, and diversity, as well as on forest ecosystem processes and functions [1-5]. In addition, it is well-known that forests provide a variety of socio-cultural and environmentally supportive services such as food provision, flood dissipation, temperature regulation, water purification, recreation, and nutrient cycling [6]. Hurricanes constitute a driver of ecosystem change that affects the delivery of tangible and intangible benefits provided by forests to sustain life, including human society and all other organisms. Effects of hurricanes on forests can be dramatic and subtle, predictable and unpredictable, and can occur in short-, mediumand long-term time scales $[5,7]$. 
On September 20, 2017, two weeks after category-5 Hurricane Irma passed to the northeast, Hurricane María made landfall on the Caribbean island of Puerto Rico as a powerful category-4 hurricane with winds of $249 \mathrm{kmh}(155 \mathrm{mph})$. Nearly 90 years had passed since the island experienced the direct hit of a storm with winds of such magnitude (a category-5 hurricane in 1928 known locally as San Felipe II). After Hurricane San Felipe II, Hurricane María is the most-intense recorded hurricane to directly affect the island [8]. Hurricane Maria's trajectory, from southeast to northwest, caused massive destruction on the island. Winds, rain, floods, and landslides led to the collapse of telecommunications, roads, and buildings; and to the breakdown of essential services such as water and electricity. It also resulted in great changes in the landscape and to the island's forests and vegetation.

Passage of hurricanes Irma and María provide opportunities to conduct studies on the disturbance effects on forest ecosystems and to produce new knowledge that can broaden our understanding of hurricanes and forests in Puerto Rico. This knowledge will apply to a broad range of geographic areas increasingly predicted to be exposed to these disturbances as well. To guide such research, we need to know what has already been studied, where this work was conducted, and which approaches were used. Within this context, and with the goal of providing insight for future post-hurricane research, we present the results of a systematic literature review of peer-reviewed articles regarding ecological research conducted in Puerto Rico on the topic of hurricanes and forests, published from 1900 to 2017. More specifically, the objectives of this research were to determine what was studied about hurricanes and forest on the island, identify gaps in information, and recommend areas of needed research. Findings are summarized and discussed in terms of the aspects of forests that were studied, the time scales, approach from which the investigations were carried out, and the geographic distribution of the study areas. Results from the review are also given in the context of a summary of cyclonic activity on the island during the 117-year study period and presented in the following section.

\section{Forest and Cyclones in Puerto Rico: A Brief Overview}

Puerto Rico, the easternmost of the Greater Antilles in the Caribbean region, is home to 3,195,153 inhabitants [9] representing a population density of 360 people $/ \mathrm{km}^{2}$, with the coastal areas being the most densely populated [10]. The most recent estimate of Puerto Rico's forest revealed approximately $55 \%$ of the island's area is covered by forest, ranging from mangrove and dry forests in the coastal regions to wet/rain and lower montane forests at higher elevations [11]. Meanwhile, about $13 \%$ of the island's forests and $60 \%$ of forested wetlands are under protected status including commonwealth forests, wildlife refuges, natural reserves, among others [12].

The geographic position of Puerto Rico within the Atlantic Basin exposes its residents, infrastructure, and ecosystems to tropical cyclones from June through November, with most storms occurring in August and September [8]. Based on compiled National Oceanic and Atmospheric Administration tropical cyclone tracks for this region from 1900 to 2017, a total of 70 cyclones passed over Puerto Rico or within a distance of $138 \mathrm{~km}(86 \mathrm{miles})$ or less from the island's coasts (following the methodology of Reference [8]). In terms of intensity, and based on the Saffir-Simpson scale, 37 of those cyclones were tropical storms and 33 were hurricanes: 10 were category- 1 hurricanes and nine were category-2, while 14 hurricanes reached wind velocities of intense hurricanes (this is, category-3 or more). Of the 14 intense hurricanes, five were category-3, six were category-4, and three reached maximum intensity (category-5). Twenty-one (21) of the 70 cyclones made landfall, 10 as tropical storms and 11 as hurricanes (three category-1; three category-3; two category-3; two category-4; and one category-5). Regarding trajectory, nine of the 21 cyclones that made landfall crossed through a large area; their paths from southeast to northwest or from east to west affected most of the island. Trajectory of the remaining 12 cyclones was more localized over a smaller portion of the island. Forty-nine (49) of the 70 cyclones did not make landfall; 28 passed north or northeast of the island, and 18 moved south or southwest. Three cyclones had unusual trajectories, from southwest to northeast. Of the 49 cyclones not making landfall, 27 were tropical storms, and 22 were hurricanes: seven category-1, six category-3, three category-3, four category-4, and two category-5. 


\section{Methods}

\subsection{Systematic Literature Review}

Systematic literature reviews are used as a method to assess, examine, and summarize the state of knowledge and understanding on a given field, topic, or research question using organized and replicable steps [13]. They have been used to identify, classify, and summarize trends in human-environment related research including topics such as species conservation [14], species distributions [15,16], natural hazards and disasters [17], floods and droughts disaster planning and preparedness [18], climate change vulnerability and adaptation [19], carbon accounting [20], and urban rivers ecology [21]. In the present study, we conducted a systematic literature review to highlight the scope and trends in cyclones and forests research conducted on Puerto Rico between 1900 and 2017.

\subsection{Article Search and Selection}

The systematic literature review for this study was based on a search conducted using the Web of Science Citation Index, a search engine that gives access to multiple databases covering the natural sciences, social sciences, arts, and humanities [22]. We searched articles published between 1900 and 2017 (the year 1900 was used given that the index used provided information from that year onward) using a keyword search with a combination of words including the geographic area of interest (Puerto Rico), the hazard of interest (hurricane), and the ecosystem of interest (forest). To assure all possible articles were identified in the search, we included associated terms in each case (Table 1). For example, with keyword "Puerto Rico", we also searched the term "Porto Rico," since early 20th century publications anglicized the name. Regarding hurricanes, we also used the term cyclone and storm, and in the case of forests we also included the words mangrove and wetlands so that all possible forest types were included. The boolean operator "AND" was used to join the keywords. Each search included a term for the geographic area, the hazard, and the ecosystem. For example: "Puerto Rico" AND hurricane* AND forest*.

Table 1. Combination of keywords used in the systematic literature review. Boolean strings included quotation marks and asterisks.

\begin{tabular}{ccccc}
\hline Geographic Area & Boolean Operator & Hazard & Boolean Operator & Ecosystem \\
\hline "Puerto Rico" & AND & $\begin{array}{c}\text { hurricane* } \\
\text { storm* } \\
\text { cyclone* }\end{array}$ & AND & $\begin{array}{c}\text { forest* }_{\text {mangrove* }}^{*} \\
\text { wetland }^{*}\end{array}$ \\
\hline
\end{tabular}

We included regional journals as part of the review process since some of these journals are not always included on databases such as Web of Science. The journals included Caribbean Geography, Caribbean Studies, Caribbean Journal of Science, and Caribbean Naturalist. Local subject bibliographies about forests in Puerto Rico were also examined [23,24]. We reviewed the tables of content of these journals and the titles on the bibliography and identified those articles that were potentially pertinent for our analysis. Moreover, we assessed the bibliographic sections of published literature review articles, summary articles, and introductions or conclusions of special issues about hurricanes and forest to identify potential articles not found in the initial database search [2-4,7,25-31]. Within the context of systematic literature reviews, this later sampling scheme was used as a snowball technique for the identification of relevant articles [14].

The search was conducted between November and December 2017. It resulted in a total of 588 articles. We retrieved the title and abstract of each article. This information was used to evaluate each article in terms of which ones were to be excluded from our analysis. For this procedure, abstracts were reviewed individually to make an initial assessment of the articles to be excluded. After the initial evaluation, all the abstracts to be eliminated were reviewed again collectively to assure that they were not related to the purpose of the analysis. There were four criteria to exclude an article: 
- Irrelevant geographic location: If a study was not conducted in Puerto Rico.

- Irrelevant content: If the content of the article was not related or relevant to the purpose of our analysis. In this case, many of the articles excluded from the analysis were those that addressed topics related to forests or hurricanes, but not specifically the influence of hurricanes on forests. There were other cases in which the hazard of study was other than hurricanes (e.g., tsunamis or fires), hence they were excluded.

- Article type: If an article was a literature review, a summary article, or introductions or conclusions of special issues. As mentioned above, these sources were used, instead, to identify potential articles to be included in our analysis.

- Repeated article: If an article appeared more than once in the search, we eliminated it after its first appearance.

Through this process we excluded 422 articles from the analysis; the remaining 166 articles were used for our review.

\subsection{Article Categorization}

We read the abstracts of the 166 selected articles to summarize further and categorize each one based on six aspects to describe the research (Table 2). In cases where the abstract provided limited information for our categorizations, we examined the entire article. The categories were:

- Focus of analysis: whether the article focused mainly on the biotic or the abiotic component of the forest ecosystem. In terms of the biotic component, articles were divided into five broad classifications based on the organism studied: plants, animals, bacteria, fungi, and protists. Sub-categorizations were created for plants and animals. Plants were further subcategorized in terms of their structure, including woody- (trees, both gymnosperms and angiosperms, and lianas) and non-woody vegetation (palms, herbaceous plants, ferns, and vines). Animals, on the other hand, were subcategorized in three phyla: Chordata (including birds, mammals, and reptiles), Arthropoda (insects, spiders, and shrimp), and Mollusca (snails only). Regarding the abiotic component as the main focus of analysis, articles were categorized based on what forest system process was studied; in this case, including fluxes and accumulation of nutrients (fluxes, rates, and cycling of single or multiple molecules and elements), decomposition (studies of leaves, litter-fall and woody decay, and decay rates), and photosynthesis (including measurement of leaf photon flux or similar). Finally, we noted any studied interactions between any of these components, for example, if there were interactions between different organisms, with the abiotic component, or with other hazard types (e.g., droughts, landslides).

- Study approach: whether the research was a natural or observational experiment-where the researcher does not establish the effect, but instead selects sites or gradients where the effect is already occurring [32], a manipulative controlled experiment-where the researcher either in the field-outdoors or in a laboratory-indoors manipulates or controls variables to measure their effects [32], or a theoretical/mathematical model [33].

- Temporal scale or duration of study: the time of the study implied by the span of the collected data (days, weeks, months, years). What we refer to as temporal scale could be different from the sampling regime of the study, which is something not addressed in our analysis.

- Studied hurricane: the hurricane(s) or tropical storm(s) that was (were) the focus of analysis. We also noted cases when effects of multiple cyclones were studied.

- Year of publication: the year each article was published.

- Geographic focus: the geographic location of the study area, whether the sites were in protected or non-protected areas, and the environmental setting in which the study areas occurred (very wet/humid, wet, or dry zones). In terms of the geographic location of the studies, the specific geographic location (following geographic coordinates) was noted when this information was 
available. Otherwise, the general location of the study was assigned based on toponymical site description.

Table 2. Summary of data categorization.

\begin{tabular}{cl}
\hline Main Category & \multicolumn{1}{c}{ Elements Included in Subcategories } \\
\hline \multirow{2}{*}{ Focus of analysis } & $\begin{array}{l}\text { Biotic: Plants } \\
\text { (Woody: trees, liana; Non-woody: palms, Herbaceous plants (ferns, vines, others) } \\
\text { Biotic: Animals } \\
\text { (Chordata phylum: birds, mammals, reptiles; Arthropoda phylum: insects, spiders, } \\
\text { shrimp; Mollusca phylum: snails) } \\
\text { Non-biotic: Fluxes and accumulation of nutrients; Decomposition; Photosynthesis }\end{array}$ \\
\hline \multirow{2}{*}{ Study approach } & $\begin{array}{l}\text { Natural or observational } \\
\text { Manipulative controlled } \\
\text { Theoretical/mathematical }\end{array}$ \\
\hline Temporal scale & $\begin{array}{l}\text { Days to weeks (less than a month); Months (less than a year); Year (one to less than } \\
\text { two years); Multiannual (two years or more) }\end{array}$ \\
\hline Geographic focus & Protected or non-protected area; Environmental setting (very wet/humid; wet; dry) \\
\hline
\end{tabular}

\subsection{Analysis}

Analysis of the categorized data consisted of the generation of basic descriptive statistics (i.e., counts and percentages). Percentages were calculated either in terms of the total number of the articles analyzed (166) or relative to the number of articles within each category and subcategory described. In terms of counts, there were cases where double counting was allowed. If, for example, one article studied two types of plants (one woody and one non-woody) or had study areas in more than one location, then that article was recorded more than once for each classification.

\subsection{Study Delimitations and Limitations}

Our analysis was limited to articles published in English in scholarly journals during the years 1900 to 2017 identified through a search based on the Web of Science Citation Index and through several selected regional journals, bibliographies, literature review articles, summary articles, and introductions or conclusions of special issues. There are some limitations of the data that we want to point out so that the results and implications of our study are analyzed in the light of such constraints. These include the exclusion of relevant publications that appear in books, book chapters, and other publications; Spanish language publications; and non-refereed published materials such as technical reports, working papers, and conference proceedings in printed format or other mediums such as the Internet.

Despite the above-mentioned limitations and constraints, we believe that the data and analysis presented in the article provide a good overview of what has been studied and published regarding hurricanes and forest ecosystems in Puerto Rico. To our knowledge, a systematic review of academiclevel research regarding these topics has not been conducted and published. Such analysis is valuable for researchers and practitioners who conduct work on these topics because it helps identify gaps in information and research needs and to stimulate further, and more detailed, analysis for production of new knowledge.

\section{Results}

\subsection{Focus of Analysis, Study Approach, and Duration}

The majority ( 141 or $84.9 \%$ ) of the 166 articles analyzed addressed elements of the biotic component of the ecosystem, while the remaining $15 \%$ focused on abiotic components. Of articles studying organisms, plants were the main focus of study ( 85 articles, $60.3 \%$ of the biotic-related articles), 
followed by animals (52 articles, 36.9\%), bacteria (two articles, $1.4 \%$ ), fungi (one article, $0.7 \%$ ), and protists (one article, $0.7 \%$ ).

Most of the 85 plant-focused articles (82.2\%) studied the effect of hurricanes on woody vegetation, compared to $34.1 \%$ focusing on non-woody vegetation and $5.8 \%$ on ferns. In the case of woody vegetation, trees were the main organism studied ( $96 \%$ of those articles), most on angiosperm trees with only three articles focused on gymnosperms trees (pines), and two on lianas. Among those articles focusing on non-woody vegetation, most (65.5\%) studied palms, followed by herbaceous plants $(17.2 \%)$, and vines $(10.3 \%)$. The majority of articles $(75.3 \%)$ studied plants individually; $20 \%$ studied trees and palms in combination, while $4.7 \%$ of studies included herbaceous plants, vines, ferns, or trees. The majority of studies focusing on plants considered the effects of hurricanes on species abundance, diversity, tree structure, and tree community composition in long- and medium-time spans. Several concentrated on seedling dynamics, including mortality and recruitment. Fewer than half of the plant studies focused on short- to medium-time spans of hurricane responses including assessment of mortality, canopy structure, defoliation, uprooting of trees, and structural effects. Only a few studies focused on seeds, root systems, herbivory, and phenology. While most of the studies focused on the sole effects of hurricanes on plants, a portion of them (22.4\%) studied the combined effects of storms and other aspects of the biotic component (i.e., human interaction through past land use and herbivory) or related to abiotic processes. One article considered the effects of hurricanes on plants in conjunction with the effects of another hazard type (landslides).

More than a third (36.9\%) of the articles focused on animals as the primary organism of analysis; organisms within the Chordata phylum were the most studied, followed by the Arthropoda and the Mollusca Phyla (studied in $36.5 \%$ and $13.5 \%$ of those articles, respectively). Within the Chordata phylum (27 articles), birds were most commonly studied (55.6\% of animal articles), followed by mammals $(14.8 \%)$, and reptiles (7.4\%). Insects were the most studied organism within the Arthropoda phylum (15 of 19 articles, $78.9 \%$ ), followed by spiders and shrimp (15.8\% each). All articles (seven) addressing the Mollusca phylum were comprised of snail studies. Most articles that focused on animals included hurricane responses regarding survivorship rates, abundance, density, species richness, and composition. Fewer studies described reproductive success relative to food availability and predation, variation in diet, regional migration, home ranges, site fidelity, and movement patterns. The fewest studies included body size and body mass, variation in color patterns, herbivory, and parasite prevalence. Moreover, most of the articles $(96.2 \%)$ researched an animal category individually; only two articles studied insects and spiders in conjunction. Additionally, approximately one-third of the articles looked at interactive effects of hurricanes in relation to other organisms and processes (e.g., human interaction through past land use, herbivory, competition for resources, defoliation). Two articles addressed effects of hurricanes on animals in relation to the effect of another hazard type (drought).

Bacteria, fungi, and protists were the least-studied components of the biotic system. Bacteria were the focus of analysis in two of the 141 organism-related articles, while fungi and protists were each addressed in one article. In all cases, hurricane effects on these organisms were studied in conjunction with other processes (i.e., past land use), other organisms, or processes of the abiotic system (i.e., element cycles, decomposition). The studies on bacteria and microorganisms focused on soil and leaf litter including, for example, relative abundance and community functional diversity. The fungi-focused article included element content (Phosphorous) and fungal connectivity on decomposing leaves.

The remaining $15.1 \%$ of the 166 analyzed articles addressed the abiotic component of forest ecosystems as their primary analysis focus. The most studied process was fluxes and accumulation of nutrients $(68.0 \%)$, followed by decomposition (24.0\%), and photosynthesis (8.0\%). Most articles $(84.0 \%)$ discussed the sole effect of hurricanes in the abiotic system and related processes; only four articles addressed the interactive effects of the abiotic and biotic systems and resulting hurricane effects. These included interactions regarding past land uses, and with other organisms (i.e., decapods/shrimp and trees). 
In $78.9 \%$ of the analyzed articles, research was done as a natural or observational experiment, $15.1 \%$ consisted of manipulative controlled trials, and $6.0 \%$ were from mathematical/theoretical models. Study duration primarily consisted of multiannual studies (68.1\%) and one-year studies (15.7\%), while the rest were conducted in a matter of months $(5.4 \%)$ or days to weeks $(3.6 \%)$. Organisms or processes studied in these short-term projects included animals (for example, birds, shrimp, snails, insects, and spiders, and associated aspects, such as species abundance and predation), plants (herbaceous and tree seedlings), as well as abiotic processes (including nutrient fluxes in water and vegetation). These studies were generally conducted immediately or within a short time after a hurricane occurrence.

\subsection{Studied Hurricanes and Years of Publication}

Of the 70 cyclones passing over or near the coasts of Puerto Rico during the 117-year study period, only 16 were the focus of study in the examined articles, eight of which made landfall and eight that did not (Figure 1). The first studied hurricane was a category-5 hurricane that made landfall in 1928, known locally as San Felipe II. The most studied hurricane, however, was Hugo, a category- 4 hurricane, the center of which crossed the island municipality of Vieques and then passed through northeastern Puerto Rico in 1989. Hurricane Hugo was the focus of study in 108 articles (65.0\%). The second most studied hurricane was Hurricane Georges, a category-3 hurricane that made landfall 10 years after Hurricane Hugo, in 1998, and whose center crossed the island from east to west. Hurricane Georges was studied in 66 (39.8\%) articles. The remaining 14 hurricanes were analyzed in fewer than four articles each. There were 13 other cyclones that made landfall on the island during the study period but were not part of the analysis in any of the examined articles.

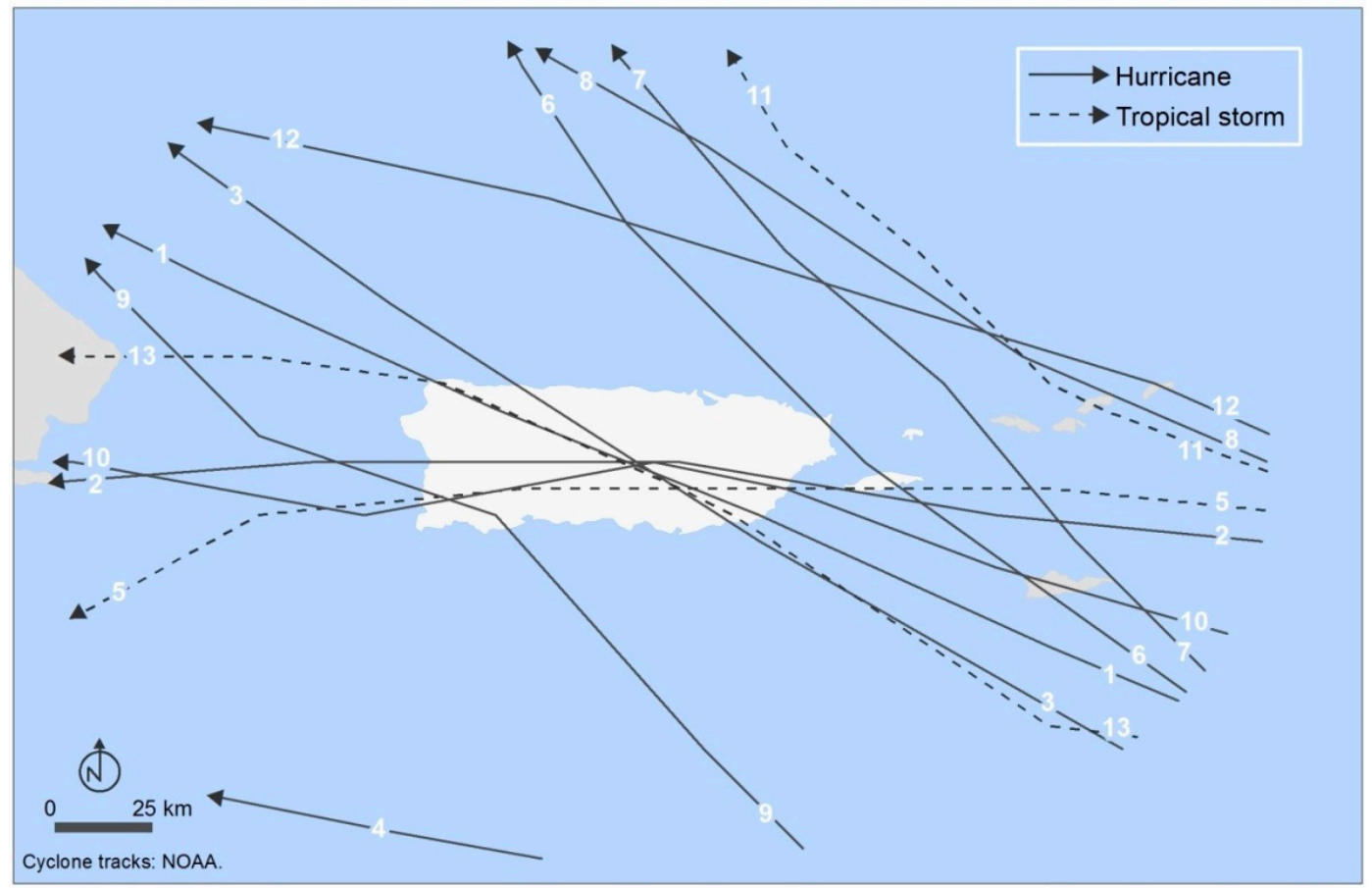

Figure 1. Trajectories of hurricanes studied in the examined articles. The 13 hurricanes that passed within 138 km of Puerto Rico identified by number are 1. San Felipe II (1928) 2. San Ciprián (1932) 3. Betsy (1956) 4. David (1979) 5. Frederick (1979) 6. Hugo (1989) 7. Marilyn (1995) 8. Bertha (1996) 9. Hortense (1996) 10. Georges (1998) 11. José (1999) 12. Debbie (2000) 13. Jeanne (2004). Three other hurricanes that passed at areater distance are not shown in this map (see Forest and Cyclones in Puerto Rico: A Brief Overview section).

In more than half of the articles $(65.7 \%)$, hurricanes were studied individually. For instance, Hurricane Hugo was solely studied in $44.0 \%$ of the articles, while Hurricane Georges was studied 
alone in $19.9 \%$ of them. There were 21 articles $(12.7 \%)$ in which the effect of two or more hurricanes in forest ecosystem were taken into account. In this case, the interactive effects of hurricanes Hugo and Georges were addressed the most.

The first published article we identified was from 1930, regarding hurricane effects on trees by a category-5 hurricane in 1928 (San Felipe II). The peak of publications was in 1991, two years after the passage of Hurricane Hugo (Figure 2). For that year we identified a total of 17 published articles, including articles in a publication of a 1991 Biotropica Special Issue regarding ecosystem, plant, and animal responses to hurricanes in the Caribbean. Two other years with high numbers of publications were 1996 and 2014, with the publication of 12 articles in each year. Hurricanes Hugo and Georges stimulated many of the ecological studies concerning hurricane effects in Puerto Rico. Not only were these the most studied hurricanes, but the publication of articles based on research about hurricane effects on forest ecosystems has lasted many years after their passage over Puerto Rico. Publication of articles on Hurricane Hugo spanned 1990 to 2017; articles addressing Hurricane Georges were published from 2000 to 2017.

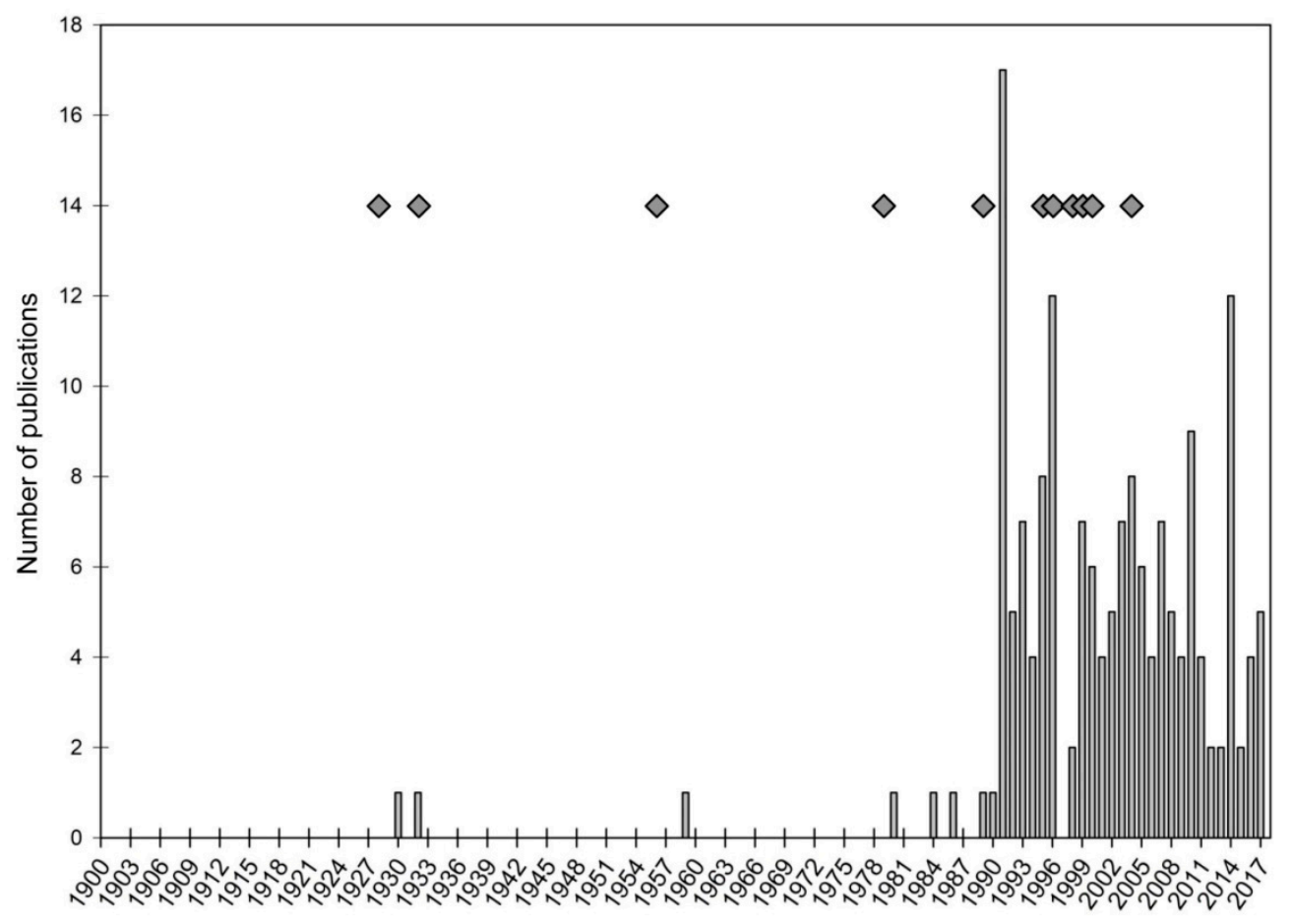

Figure 2. Number of publications per year obtained from the systematic literature review with hurricanes and storms identified (rhombus symbol).

\subsection{Geographic Location of Studies}

There were 43 sites across the island where the published research was conducted. Sixteen (16) of these sites were in protected areas, versus 27 in non-protected areas (Figure 3). The majority of the resulting articles, however, took place in protected areas. The Luquillo Experimental Forest (also known as El Yunque National Forest, hereinafter LEF) in northeastern Puerto Rico was the site of most studies (142 articles or 85.5\%). Most research associated with Hurricane Hugo was conducted in the LEF, but its passage also promoted studies in 19 other sites around the island (Figure 4). Hurricane Betsy in 1956 (known locally as Hurricane Santa Clara) and Hurricane Georges were the other two hurricanes which resulted in a range of different study sites. The trajectories from southeast to northwest of Hurricane Betsy, and from east to west of Hurricane Georges, resulted in studies conducted in 19 and 22 sites across the island, respectively. 


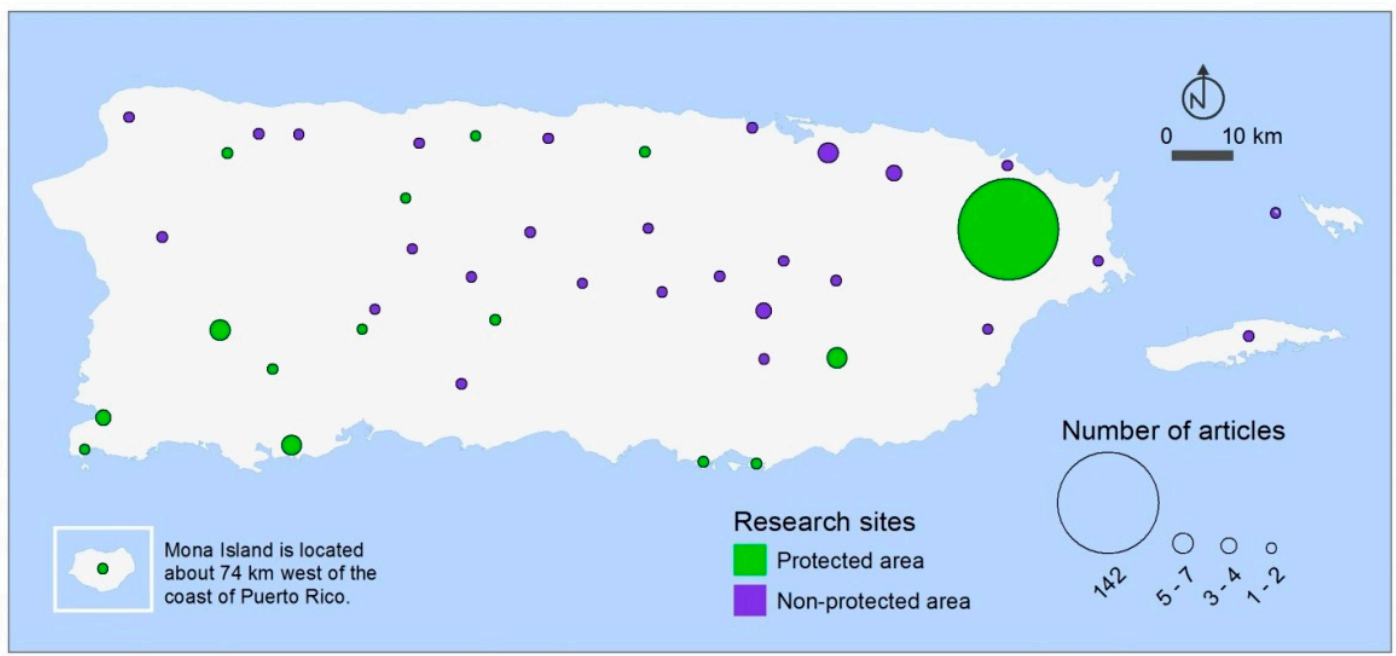

Figure 3. Location of study sites categorized by protection status and number of articles published.

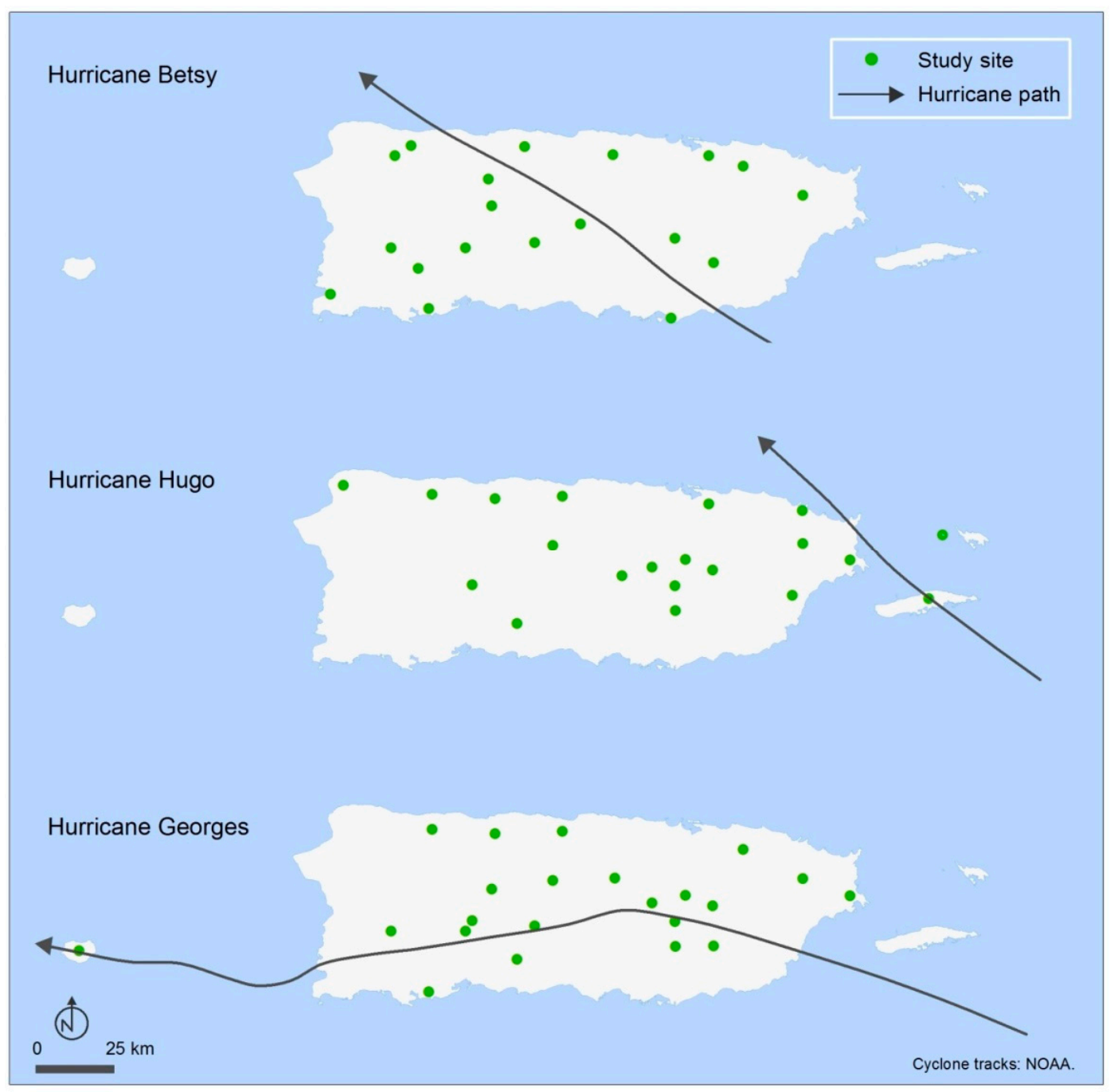

Figure 4. Location of study sites in relation to hurricanes with different trajectories across the island.

Other protected areas where studies took place, although at a much lower rate compared to the LEF, were Guánica Commonwealth Forest (seven articles), Maricao Commonwealth Forest (six articles), and Carite Commonwealth Forest (five articles, Figure 5). In the remaining 12 sites within protected 
areas, there was a maximum of three articles associated with each. While there were more study sites located in non-protected areas (27 compared to 16 in protected areas), only 48 articles $(28.9 \%)$ resulted from research conducted in those sites. The municipality of San Juan held the most studies in non-protected areas, with five published articles.

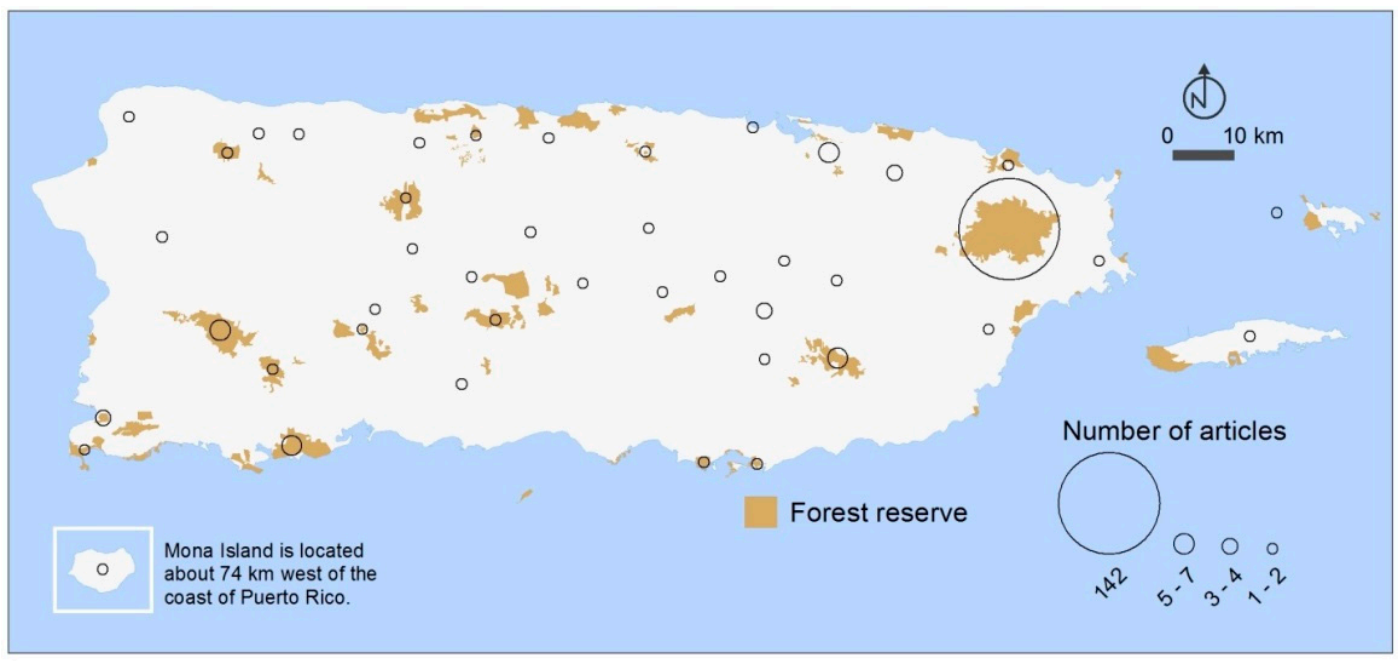

Figure 5. Location of study sites with number of articles published and geographic distribution of forest reserves.

Regarding climatic settings, most studies $(91.0 \%)$ were carried out in very wet/humid locations and mostly within the LEF (Figure 6). About $18 \%$ of the remaining studies took place within the island's wet $(9.6 \%)$ or dry zones (9.0\%). Most articles (92.2\%) addressed only one zone; 10 articles $(6.0 \%)$ included two or more zones as part of their study sites.

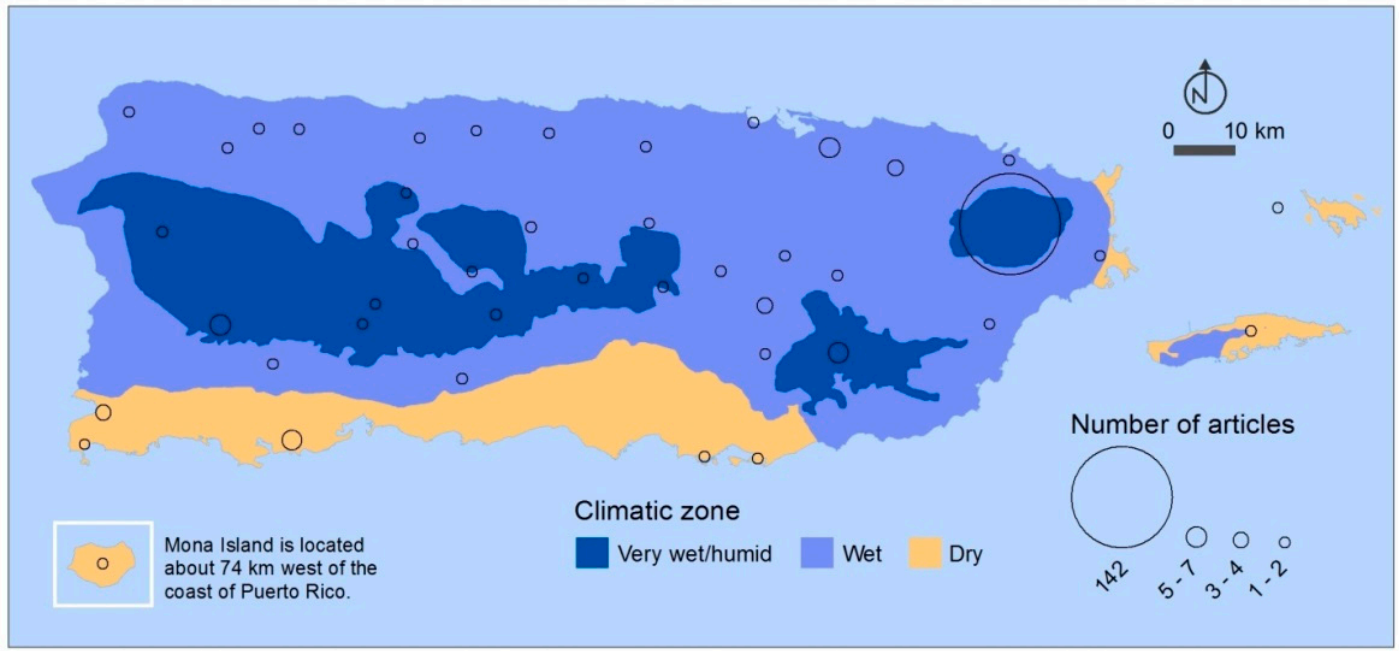

Figure 6. Location of study sites with number of articles published in relation to climatic zones.

\section{Discussion}

Research about forest and hurricanes in Puerto Rico, particularly from mountainous sites and wet zones, provides unique insight on short-term and long-term observations of forests during posthurricane dynamics. Such research has been referenced regionally and contributes to understanding hurricane and forest dynamics regionally in Nicaragua [34], Jamaica [35,36], Guadeloupe [37], as well as worldwide in places like Hawaii [38], Solomon Islands [39], Philippines [40], Taiwan [41,42], Japan [43], and Australia [44]. New information from studies arising from hurricanes Irma and María will further contribute to our knowledge of hurricanes and forests in the Caribbean region and beyond. 
The systematic literature review allowed the identification of researched topics, of what is missing, where the information is available, and where it is not. As a fundamental component of forests, trees were one of the most studied aspects of these systems. Tree responses to hurricanes, including distribution of the most common tree species across time during multi-decadal recovery processes, accumulation of biomass, and density of individuals, have strong foundational knowledge from research conducted in Puerto Rico [45-49]. What is less common are studies that contribute to the understanding of other forest elements such as rare and endemic species, non-tree vegetation, and aquatic organisms.

There are few studies of rare and endemic species in forests after hurricanes. These species may contribute insights into selection pressure, genetics, and the evolutionary processes of those species that have survived and been selected for in hurricane-prone zones. Research is needed on various types of animals and plants, freshwater fauna, microorganisms, and rare and small plants like bryophytes, epiphytes, and herbs, for example, as well as fungi. Bryophytes and epiphytes, for instance, are characteristic components of rain and cloud forests but these rare or uncommon plants are severely understudied, particularly within the context of hurricanes. Reviewed studies on rare plants, moreover, found contrasting post-hurricane effects depending on the study location and the hurricane. As an example, a study on epiphytic orchids living in montane forest canopy tree branches reached different conclusions from a study of terrestrial orchids in a coastal forest [50,51]. The location of study sites and the broad environmental conditions in which hurricane effects take place are, consequently, important variables to take into consideration. Even in studies on common organisms such as trees, location within a landscape with varied conditions (e.g., geomorphological setting, aspect, orientation) provides essential context to interpret observations and findings [52-54]. Most of the identified studies come from mountainous sites (particularly from the Luquillo Experimental Forest, LEF). Hence, the spatial context of study locations with different landscape characteristics must be increased to better understand and expand knowledge regarding the effects of hurricanes on organisms and ecosystem processes.

Hurricane effects on forest structure such as branch breakage, reduction in complexity of canopy structure, and wind shear effects are also documented, and in some cases, these changes in forest structure have been associated with various plant and animal interactions. These interactions and processes, however, can occur at different temporal scales. For example, the process of forest canopy re-growth occurs at a time beyond the immediate resource needs of birds that depend on flower nectar and fruits $[31,55]$. Further, in the short term, the timing of flowering and fruit-bearing may become decreased, delayed, or asynchronous with bird populations that depend on those resources. Successional dynamics of non-tree understory vegetation (e.g., ferns, herbs) are also altered with changes in forest canopy structure. These effects can include changes in the abundance and dominance of various vegetation types, which display drastically different times to recovery-some greater than 20 years [56]. Finally, the ephemeral changes in forest light and structure associated with reduced tree canopy immediately after hurricane passage offer unique opportunities to conduct studies of altered conditions. Therefore, aspects associated with temporal scales of ecological processes in the aftermath of hurricanes is something that must be taken into consideration on future research.

Although a small proportion of studies focus on hurricane effects in forest ecosystem processes, many of these are long-term studies, and thus able to provide fundamental information by comparing conditions and processes before and after hurricane events. These studies of forest ecosystem process and hurricanes are also some of the highly cited publications in different types of forests and ecosystems beyond the study sites $[48,57,58]$. These types of studies require investment in instrumentation beyond field work, and most have an additional laboratory component. Some studies may stall when access to study sites and facilities are limited after hurricanes, but most ecosystem process studies have successfully continued long-term in Puerto Rico and should be further encouraged. Studies combining an observational approach with other experimental designs are also needed, as mechanistic insights 
and understanding has been obtained through studies that combine manipulative experiments and mathematical modeling [28,59].

Addressing the historical context of studied hurricanes, as well as hurricane trajectory and other physical characteristics is important. Hurricane tracks can influence study sites and, consequently, the type of forest being studied. For instance, Hurricane Hugo (1989), with a trajectory east of the LEF, promoted a wealth of ecological studies around this forest reserve. Nearly a decade later, the east-to-west trajectory of Hurricane Georges (1998) allowed the study of hurricane effects in other forest types and settings, including, coastal areas and dry forests.

Conditions such as time since last hurricane event at a study site are critical in the process of understanding forest dynamics. This changing aspect of forests and hurricanes was highlighted in early ecological publications from Puerto Rico that identified on-going forest succession dynamics (e.g., [45]). Many of the effects observed after hurricanes (e.g., landslides, floods, and erosion) are dependent on local environmental conditions particular to each hurricane. In Puerto Rico, prior to Hurricane Hugo there was a lapse of 57 years between intense (category-3 or higher) hurricanes on the island, the most recent previous one being the category-3 hurricane known locally as San Ciprián in 1932. Additionally, almost 20 years passed between the most recent land falling hurricanes, Hurricane Georges in 1998 and Hurricane María in 2017. Environmental conditions (such as local climate) change through time and between cyclonic events. Further, conditions right before and after hurricane events may also be different. After Hurricane Hugo, there was reduced rainfall (local drought conditions), whereas continuous rainfall events and floods occurred after Hurricane María. With an increase in data and understanding of hurricanes and forests, we realize the complexity of interactions among forest components upon such events. Because each storm happened in a different context, differences in the time scale of hurricane occurrence, associated changing environmental conditions, and cumulative interactions, must be continuously accounted for when interpreting hurricane effects in forest ecosystems.

Regarding the geographic location of studies, most research comes from sites in protected areas, particularly the LEF in northeastern Puerto Rico. Various factors account for the greater quantity of published studies coming from protected areas. In the case of the LEF, this is particularly due to its designation as an experimental forest established as an area for research purposes. Research forests and protected forests serve to incentivize the establishment of permanent research projects, as many of these areas have supporting institutions, physical and research infrastructure, and personnel that are present at the site [60]. Such is the case of the LEF, where research is built upon incremental knowledge from the same study sites within the protected research area such as the Bisley Experimental Watersheds and El Verde Research Area (e.g., [1,27,61,62]). The disproportionately high number of studies in the LEF is also due to the institutions (i.e., University of Puerto Rico and USDA Forest Service International Institute of Tropical Forestry) with committed personnel, investment in long-term funding, support, field stations, and other infrastructure to promote and facilitate research [60]. The other site with multiple published studies is the Guánica Commonwealth Forest, a protected area on the island's southern coast. This site is a Puerto Rico Department of Natural and Environmental Resources forest reserve. While the physical and research infrastructure here is not as expansive as that at LEF, there are long-term research records, and researchers who conduct work at this site are committed to long-term studies (e.g., [63-65]). The forest at Guánica includes coastal areas, with various plant communities including dry forests, scrub or shrublands, and mangrove forests. Studies at Guánica include long-term research projects and are significant contributors to knowledge of hurricanes and forests in Puerto Rico with broader application referenced in the wider Caribbean and other tropical sites worldwide $[37,66]$. Reserved forest areas that include research designations, institutional commitment, and scientists with long-term research perspectives facilitate the establishment of permanent, experimental, and innovative research projects which uniquely contribute to the understanding of fundamental dynamics and processes $[25,45,46,67]$. However, it is important that research from these sites is kept in perspective 
regarding how representative the sites are to broader landscapes and regions [68] because of their essential role as drivers of knowledge generation on hurricanes and forests.

Research from study sites in protected areas is also mostly in mountainous regions, where forests occur in a landscape matrix of forested land (forest surrounded by forest). Studies in non-protected areas within an array of diverse land uses and human activities are considerably fewer. While changes in land-use/land cover has been addressed in studies of hurricane effects on forests in Puerto Rico (e.g., [59,69-74]), more such studies are needed in a variety of forest types, particularly in non-forested landscape matrices. Emphasis should be given to studies examining forest sharing edges with urban areas, as forests embedded in urbanized landscapes are part of hurricane-prone landscapes in Puerto Rico. Further, hurricane effects on coastal areas, including both fresh- and saltwater forest systems, have been less documented than montane regions. Currently, the vast majority of knowledge about hurricanes and forests comes from very wet and humid areas. Relatively few studies address coastal forests (such as mangrove wetlands) and hurricanes, even though coastal areas undergo multiple processes such as reduced area due to land-use change (as is the case of urban expansion) and sea level rise [75]. Forests in coastal areas not only take the direct effects of hurricanes, they also receive influx from mountain forests via watershed processes in the form of floods, with organic matter and sedimentation; all of which results from and interacts with hurricane effects. Although we know of these dynamics, rarely are they tied together in a single study, for example, assessing hurricane-caused mountain slide and river flood effects on coastal forest systems. Research conceived to integrate interactions between various forest types, whether montane and coastal areas, riparian zones, wet or dry, are still limited.

\section{Concluding Remarks and Recommendations: Where and What Should We Study Now?}

The analysis of the systematic literature review revealed different gaps in information and information needs, thus providing insights for future research about hurricanes and forests:

- More studies on rare, native, and endemic species provide insights regarding hurricane effects on these relatively less-studied species. Additionally, more studies about fungi and their effects and functions on post-hurricane forests are needed.

- Studies of potential interactive effects of hurricanes with different biotic and abiotic components of forest ecosystems are needed, as most hurricane impact studies are of individual species or as related to a single abiotic component. Likewise, more research studying the combined effects of different disturbances on forest ecosystems (e.g., hurricanes, landslides, and drought) can increase our understanding of various hazards and forests processes.

- Studies and data collected at different temporal scales are needed. Studying the immediate effects of hurricanes on species and forest processes could provide new and valuable information. Some processes and effects on forest components are ephemeral or can be more easily detected shortly after hurricane occurrence; not studying them at the appropriate temporal scale can result in a missed opportunity to expand our knowledge base.

- Continuing and increasing the number of long-term studies is also important. In this respect, addressing the historical context of hurricanes and forest ecosystem studies is critical in understanding forest processes (including, for example, forest recovery). In this sense, it is crucial to take into consideration, and study, the cumulative effects on forests of different hurricanes thru time, as well as the varying physical, environmental, and anthropogenic conditions in which hurricanes occur. Hurricanes Irma and María (2017), along with the wealth of studies generated in the aftermath of hurricanes Hugo (1989) and Georges (1998), provide an opportunity to increase the number of long-term studies and understand hurricane effects on forest ecosystems within different contexts and at different temporal scales.

- Studies that integrate various methodological approaches are needed. Combining observational studies with other experimental approaches (such as manipulative experiments and modeling) will 
provide a better understanding of hurricane effects on ecosystem processes and of the mechanisms associated with these processes.

- Studies in more diverse habitats and forest types with varying geologic, edaphic, geomorphologic, topographic, and climatic conditions are needed as most published studies were conducted in montane and wet zones. More studies on the effects of hurricanes on coastal forest (including both fresh- and saltwater forest systems, for example) are needed. Studies integrating different environmental conditions from mountain to coastal areas should be encouraged.

- Studies taking place in non-protected areas and within different landscape matrices (other than forests surrounded by forests) and human interactions (as those forests sharing edges with urban land cover and within areas with different land-use history, for example) are greatly needed. This approach is increasingly important to consider as dynamic forest-landscape changes and human interactions increase.

The recommended research topics, approaches, and associated new knowledge perspectives are not only valuable for management implications and learning more about the interaction of forests and hurricanes in Puerto Rico, but also serve to provide insights applicable to worldwide areas currently experiencing—and those areas predicted to be increasingly exposed to—-these atmospheric events.

Author Contributions: T.L.M. conceived the original project idea. T.L.M., T.H.S., C.F.R.L., I.A.E.G., and M.E.R. collected, processed, and categorized the data. T.L.M. and T.H.S. analyzed and interpreted the data and wrote the manuscript. All authors revised and approved the submitted version of this manuscript.

Funding: This research received no external funding.

Acknowledgments: Gisel Reyes (since retired) staff librarian at the Frank H. Wadsworth Library, USDA Forest Service International Institute of Tropical Forestry facilitated collected thematic scientific literature reports. Wayne Arendt and Ariel E. Lugo, USDA Forest Service International Institute of Tropical Forestry, contributed comments and revisions. Editorial assistance provided by Tamara Enz. The findings and conclusions in this publication are those of the authors and should not be construed to represent any official USDA or US Government determination or policy.

Conflicts of Interest: The authors declare no conflict of interest.

\section{References}

1. Brokaw, N.; Crowl, T.; Lugo, A.; McDowell, W.; Scatena, F.; Waide, R.; Willig, M. A Caribbean Forest Tapestry: The Multidimensional Nature of Disturbance and Response; Oxford University Press: New York, NY, USA, 2012.

2. Brokaw, N.V.; Walker, L.R. Summary of the Effects of Caribbean Hurricanes on Vegetation. Biotropica 1991, 23, 442-447. [CrossRef]

3. Lodge, D.L.; McDowell, W.H. Summary of Ecosystem-Level Effects of Caribbean Hurricanes. Biotropica 1991, 23, 373-378. [CrossRef]

4. Waide, R.B. Summary of the Response of Animal Populations to Hurricanes in the Caribbean. Biotropica 1991, 23, 508-512. [CrossRef]

5. Xi, Z. Synergistic effects of tropical cyclones on forest ecosystems: A global synthesis. J. For. Res. 2015, 26, 1-21. [CrossRef]

6. Millennium Ecosystem Assessment. Ecosystems and Human Well-Being: Synthesis; Island Press: Washington, DC, USA, 2005; p. 137.

7. Lugo, A.E. Visible and invisible effects of hurricanes on forest ecosystems: An international review. Austral Ecol. 2008, 33, 368-398. [CrossRef]

8. López-Marrerro, T.; Castro-Rivera, A. Actividad Ciclónica en Puerto Rico y Sus Alrededores: 1867 al 2017; Centro Interdisciplinario de Estudios del Litoral: Mayagüez, Puerto Rico, PR, USA, 2018.

9. US Census Bureau. American Factfinder Community Facts. 2018. Available online: https://factfinder.census. gov/faces/nav/jsf/pages/community_facts.xhtml (accessed on 12 April 2019).

10. López-Marrero, T.; Acevedo-Muñiz, O. Dinámicas Poblacionales en Los Municipios Costeros de Puerto Rico: 1980 al 2015; Centro Interdisciplinario de Estudios del Litoral: Mayagüez, Puerto Rico, PR, USA, 2016.

11. Marcano-Vega, H. Forests of Puerto Rico, 2014; Resource Update FS-121; USDA Forest Service, Southern Research Station: Asheville, NC, USA, 2017; p. 4. 
12. Quiñones, M.; Gould, W.A.; Castro-Prieto, J.; Martinuzzi, S. Spatial Analysis of Puerto Rico's Terrestrial Protected Areas; IITF-RMAP-03; USDA Forest Service, International Institute of Tropocal Forestry: Río Piedras, PR, USA, 2013.

13. Ford, J.D.; Berrang-Ford, L.; Paterson, J. A systematic review of observed climate change adaptation in developed nations. Clim. Chang. 2011, 106, 327-336. [CrossRef]

14. Zacarias, D.; Bini, L.M.; Loyola, R. Systematic review on the conservation genetics of African Savannah elephants. PeerJ 2016, 4, e2567. [CrossRef]

15. Bersacola, E.; Bessa, J.; Frazão-Moreira, A.; Biro, D.; Sousa, C.; Hockings, K.J. Primate occurrence across a human-impacted landscape in Guinea-Bissau and neighbouring regions in West Africa: Using a systematic literature review to highlight the next conservation steps. PeerJ 2018, 6, e4847. [CrossRef]

16. Van Wilgen, N.J.; Gillespie, M.S.; Richardson, D.M.; Measey, J. A taxonomically and geographically constrained information base limits non-native reptile and amphibian risk assessment: A systematic review. PeerJ 2018, 6, e5850. [CrossRef] [PubMed]

17. López-Marrero, T.; Hampton, J.; Vergara, E.; Quiroz, J.; Simovic, K.; Arevalo, H. Hazards and Disasters in the Insular Caribbean: A Systematic Literature Review. Caribb. Geogr. 2013, 18, 84-104.

18. Raikes, J.; Smith, T.F.; Jacobson, C.; Baldwin, C. Pre-disaster planning and preparedness for floods and drought: A systematic review. Int. J. Disaster Risk Reduct. 2019, 38, 101207. [CrossRef]

19. Ford, J.D.; Pearce, T. What we know, do not know, and need to know about climate change vulnerability in the western Canadian Arctic. Environ. Res. Lett. 2010, 5, 1-9. [CrossRef]

20. Stechemesser, K.; Guenther, E. Carbon accounting: A systematic literature review. J. Clean. Prod. 2012, 36, 17-38. [CrossRef]

21. Francis, R.A. Positioning urban rivers within urban ecology. Urban Ecosyst. 2012, 15, 285-291. [CrossRef]

22. Clarivata Analytics. Available online: https://clarivate.com/products/web-of-science/ (accessed on 15 January 2018).

23. Mosquera, M.; Feheley, J. Bibliography of Forestry in Puerto Rico; Gen. Tech. Rep. SO-51; USDA Forest Service, Southern Forest Experiment Station: New Orleans, LA, USA, 1984; p. 196.

24. Luquillo LTER Publication database. Available online: https://luq.lter.network/publications-by-year (accessed on 2 January 2018).

25. González, G.; Lodge, D. Soil Biology Research across Latitude, Elevation and Disturbance Gradients: A Review of Forest Studies from Puerto Rico during the Past 25 Years. Forests 2017, 8, 178. [CrossRef]

26. Lugo, A.E.; Rogers, C.S.; Nixon, S.W. Hurricanes, coral reefs and rainforests: Resistance, ruin and recovery in the Caribbean. Ambio 2000, 29, 106-114. [CrossRef]

27. Scatena, F.N. An Introduction to the Physiography and History of the Bisley Experimental Watersheds in the Luquillo Mountains of Puerto Rico; Gen. Tech. Rep. SO-72; USDA Forest Service, Southern Forest Experiment Station: New Orleans, LA, USA, 1989; p. 22.

28. Shiels, A.B.; Gonzalez, G.; Willig, M.R. Responses to canopy loss and debris deposition in a tropical forest ecosystem: Synthesis from an experimental manipulation simulating effects of hurricane disturbance. For. Ecol. Manag. 2014, 332, 124-133. [CrossRef]

29. Tanner, E.V.J.; Kapos, V.; Healey, J.R. Hurricane Effects on Forest Ecosystems in the Caribbean. Biotropica 1991, 23, 513-521. [CrossRef]

30. Walker, L.R.; Lodge, D.J.; Brokaw, N.V.; Waide, R.B. An Introduction to Hurricanes in the Caribbean. Biotropica 1991, 23, 313-316. [CrossRef]

31. Wiley, J.W.; Wunderle, J.M., Jr. The effects of hurricanes on birds, with special reference to Caribbean Islands. Bird Conserv. Int. 1993, 3, 319-349. [CrossRef]

32. Diamond, J. Overview: Laboratory experiments, field experiments, and natural experiments. In Community Ecology; Diamond, J., Case, T.J., Eds.; Harper and Row: New York, NY, USA, 1986; pp. 1-22.

33. Caswell, H. Theory and models in ecology: A different perspective. Ecol. Model. 1988, 43, 33-44. [CrossRef]

34. Mascaro, J.; Perfecto, I.; Barros, O.; Boucher, D.H.; De La Cerda, I.G.; Ruiz, J.; Vandermeer, J. Aboveground Biomass Accumulation in a Tropical Wet Forest in Nicaragua Following a Catastrophic Hurricane Disturbance 1. Biotropica 2005, 37, 600-608. [CrossRef]

35. Luke, D.; McLaren, K.; Wilson, B. The effects of a hurricane on seedling dynamics and abiotic interactions in a tropical lower montane wet forest. J. Trop. Ecol. 2014, 30, 55-66. [CrossRef] 
36. Luke, D.; McLaren, K.; Wilson, B. Modeling Hurricane Exposure in a Caribbean Lower Montane Tropical Wet Forest: The Effects of Frequent, Intermediate Disturbances and Topography on Forest Structural Dynamics and Composition. Ecosystems 2016, 19, 1178-1195. [CrossRef]

37. Imbert, D.; Portecop, J. Hurricane disturbance and forest resilience: Assessing structural vs. functional changes in a Caribbean dry forest. For. Ecol. Manag. 2008, 255, 3494-3501. [CrossRef]

38. Herbert, D.A.; Fownes, J.H.; Vitousek, P.M. Hurricane damage to a Hawaiian forest: Nutrient supply rate affects resistance and resilience. Ecology 1999, 80, 908-920. [CrossRef]

39. Burslem, D.F.; Whitmore, T.C.; Brown, G.C. Short-term effects of cyclone impact and long-term recovery of tropical rain forest on Kolombangara, Solomon Islands. J. Ecol. 2000, 88, 1063-1078. [CrossRef]

40. Yap, S.L.; Davies, S.J.; Condit, R. Dynamic response of a Philippine dipterocarp forest to typhoon disturbance. J. Veg. Sci. 2016, 27, 133-143. [CrossRef]

41. Lin, T.C.; Hamburg, S.P.; Hsia, Y.J.; Lin, T.T.; King, H.B.; Wang, L.J.; Lin, K.C. Influence of typhoon disturbances on the understory light regime and stand dynamics of a subtropical rain forest in northeastern Taiwan. J. For. Res. 2003, 8, 139-145. [CrossRef]

42. Lin, T.C.; Hamburg, S.P.; Lin, KC.; Wang, L.J.; Chang, C.T.; Hsia, Y.J.; Vadeboncoeur, M.A.; Mabry, C.M.; Liu, C.P. Typhoon Disturbance and Forest Dynamics: Lessons from a Northwest Pacific Subtropical Forest. Ecosystems 2011, 14, 127-143. [CrossRef]

43. Sato, T. Litterfall dynamics after a typhoon disturbance in a Castanopsis cuspidata coppice, southwestern Japan. Ann. For. Sci. 2004, 61, 431-438. [CrossRef]

44. Gleason, S.M.; Read, J.; Ares, A.; Metcalfe, D.J. Species-soil associations, disturbance, and nutrient cycling in an Australian tropical rainforest. Oecologia 2010, 162, 1047-1058. [CrossRef] [PubMed]

45. Crow, T.R. A Rainforest Chronicle: A 30-Year Record of Change in Structure and Composition at El Verde, Puerto Rico. Biotropica 1980, 12, 42-55. [CrossRef]

46. Drew, A.P.; Boley, J.D.; Zhao, Y.; Johnston, M.H.; Wadsworth, F.H. Sixty-two years of change in subtropical wet forest structure and composition at El Verde, Puerto Rico. Interciencia 2009, 34, 34-40.

47. Johnston, M.H. Successional Change and Species/Site Relationships in a Puerto Rican Tropical Forest. Ph.D. Thesis, State University of New York, New York, NY, USA, 1991.

48. Scatena, F.N.; Silver, W.; Siccama, T.; Johnson, A.; Sanchez, M.J. Biomass and Nutrient Content of The Bisley Experimental Watersheds, Luquillo-Experimental-Forest, Puerto-Rico, Before And After Hurricane-Hugo, 1989. Biotropica 1993, 25, 15-27. [CrossRef]

49. Wadsworth, F.N.; Englerth, G.H. Effect of the 1956 hurricane on forest in Puerto Rico. Caribb. For. 1959, 20, $38-51$.

50. Ackerman, J.D.; Moya, S. Hurricane aftermath: Resiliency of an orchid-pollinator interaction in Puerto Rico. Carribb. J. Sci. 1996, 32, 369-374.

51. Migenis, L.E.; Ackerman, J.D. Orchid-phorophyte relationships in a forest watershed in Puerto Rico. J. Trop. Ecol. 1993, 9, 231-240. [CrossRef]

52. Heartsill Scalley, T. Insights on forest structure and composition from long-term research in the Luquillo Mountains. Forests 2017, 8, 204. [CrossRef]

53. Lugo, A.E. Long-term response of Caribbean palm forests to hurricanes. Caribb. Nat. 2016, 1, 157-175.

54. Weaver, P.L. Tree species distribution and forest structure along environmental gradients in the dwarf forest of the Luquillo Mountains of Puerto Rico. Bois For. Trop. 2010, 306, 33-44. [CrossRef]

55. Wunderle, J.R. Pre-and post-Hurricane fruit availability: Implications for Puerto Rican parrots in the Luquillo Mountains. Caribb. J. Sci. 1999, 35, 249-264.

56. Royo, A.A.; Heartsill Scalley, T.; Moya, S.; Scatena, F.N. Non-arborescent vegetation trajectories following repeated hurricane disturbance: Ephemeral versus enduring responses. Ecosphere 2011, 2, 1-8. [CrossRef]

57. Lodge, D.J.; Scatena, F.N.; Asbury, C.E.; Sanchez, M.J. Fine litterfall and related nutrient inputs resulting from Hurricane Hugo in subtropical wet and lower montane rain forests of Puerto Rico. Biotropica 1991, 23, 336-342. [CrossRef]

58. Scatena, F.N.; Moya, S.; Estrada, C.; Chinea, J.D. The first five years in the reorganization of aboveground biomass and nutrient use following Hurricane Hugo in the Bisley Experimental Watersheds, Luquillo Experimental Forest, Puerto Rico. Biotropica 1996, 1, 424-440. [CrossRef] 
59. Uriarte, M.; Canham, C.D.; Thompson, J.; Zimmerman, J.K.; Murphy, L.; Sabat, A.M.; Fetcher, N.; Haines, B.L. Natural disturbance and human land use as determinants of tropical forest dynamics: Results from a forest simulator. Ecol. Monog. 2009, 79, 423-443. [CrossRef]

60. Meléndez Ackerman, E. Facilities. In Luquillo Experimental Forest: Research History and Opportunities; Harris, N.L., Lugo, A.E., Brown, S., Heartsill-Scalley, T., Eds.; USDA Forest Service: Washington, DC, USA, 2012; Chapter 20; pp. 127-129.

61. Harris, N.L.; Lugo, A.E.; Brown, S.; Heartsill-Scalley, T. Luquillo Experimental Forest: Research History and Opportunities; Experimental Forest and Range EFR-1; USDA Forest Service: Washington, DC, USA, 2012; p. 152.

62. Reagan, D.P.; Waide, R.B. The Food Web of a Tropical Rain Forest; University of Chicago Press: Chicago, IL, USA, 1996; p. 616.

63. Holm, J.A.; Van Bloem, S.J.; Larocque, G.R.; Shugart, H.H. Shifts in biomass and productivity for a subtropical dry forest in response to simulated elevated hurricane disturbances. Environ. Res. Lett. 2017, 12, 025007. [CrossRef]

64. Sloan, S.A.; Zimmerman, J.K.; Sabat, A.M. Phenology of Plumeria alba and its herbivores in a tropical dry forest. Biotropica 2007, 39, 195-201. [CrossRef]

65. Van Bloem, S.J.; Molina Colón, S.; Canals Mora, M.; Lugo, A.E.; Murphy, P.G.; Ostertag, R.; Rivera Costa, M.; Ruiz Bernard, I. The influence of hurricane winds on Caribbean dry forest structure and nutrient pools. Biotropica 2005, 37, 571-583. [CrossRef]

66. Curran, T.J.; Brown, R.L.; Edwards, E.; Hopkins, K.; Kelley, C.; McCarthy, E.; Pounds, E.; Solan, R.; Wolf, J. Plant functional traits explain interspecific differences in immediate cyclone damage to trees of an endangered rainforest community in north Queensland. Austral Ecol. 2008, 33, 451-461. [CrossRef]

67. Wood, T.E.; González, G.; Silver, W.L.; Reed, S.C.; Cavaleri, M.A. On the Shoulders of Giants: Continuing the Legacy of Large-Scale Ecosystem Manipulation Experiments in Puerto Rico. Forests 2019, 10, 210. [CrossRef]

68. Fahey, T.J.; Templer, P.H.; Anderson, B.T.; Battles, J.J.; Campbell, J.L.; Driscoll, C.T.; Fusco, A.R.; Green, M.B.; Kassam, K.A.; Rodenhouse, N.L.; et al. The promise and peril of intensive-site-based ecological research: Insights from the Hubbard Brook ecosystem study. Ecology 2015, 96, 885-901. [CrossRef]

69. Comita, L.S.; Thompson, J.; Uriarte, M.; Jonckheere, I.; Canham, C.D.; Zimmerman, J.K. Interactive effects of land use history and natural disturbance on seedling dynamics in a subtropical forest. Ecol. Appl. 2010, 20, 1270-1284. [CrossRef]

70. Hogan, J.A.; Zimmerman, J.K.; Thompson, J.; Nytch, C.J.; Uriarte, M. The interaction of land-use legacies and hurricane disturbance in subtropical wet forest: Twenty-one years of change. Ecosphere 2016, 7, e01405. [CrossRef]

71. Hogan, J.A.; Mayorquin, S.; Rice, K.; Thompson, J.; Zimmerman, J.K.; Brokaw, N. Liana dynamics reflect land-use history and hurricane response in a Puerto Rican forest. J. Trop. Ecol. 2017, 33, 155-164. [CrossRef]

72. Thompson, J.; Brokaw, N.; Zimmerman, J.K.; Waide, R.B.; Everham, E.M.; Lodge, D.J.; Taylor, C.M.; Garcia-Montiel, D.; Fluet, M. Land use history, environment, and tree composition in a tropical forest. Ecol. Appl. 2002, 12, 1344-1363. [CrossRef]

73. Thompson, J.; Lugo, A.E.; Thomlinson, J. Land use history, hurricane disturbance, and the fate of introduced species in a subtropical wet forest in Puerto Rico. Plant. Ecol. 2007, 192, 289-301. [CrossRef]

74. Zimmerman, J.K.; Aide, T.M.; Rosario, M.; Serrano, M.; Herrera, L. Effects of land management and a recent hurricane on forest structure and composition in the Luquillo Experimental Forest, Puerto Rico. For. Ecol. Manag. 1995, 77, 65-76. [CrossRef]

75. Yu, M.; Rivera-Ocasio, E.; Heartsill-Scalley, T.; Dávila-Casanova, D.; Ríos-López, N.; Gao, Q. Landscape-Level Consequences of Rising Sea-Level on Coastal Wetlands: Saltwater Intrusion Drives Displacement and Mortality in the Twenty-First Century. Wetlands 2019, ,1-3. [CrossRef]

(C) 2019 by the authors. Licensee MDPI, Basel, Switzerland. This article is an open access article distributed under the terms and conditions of the Creative Commons Attribution (CC BY) license (http://creativecommons.org/licenses/by/4.0/). 